ISSN: $1412-4734$

E-ISSN: 2407-8646

Volume 18, Number 1, 2018

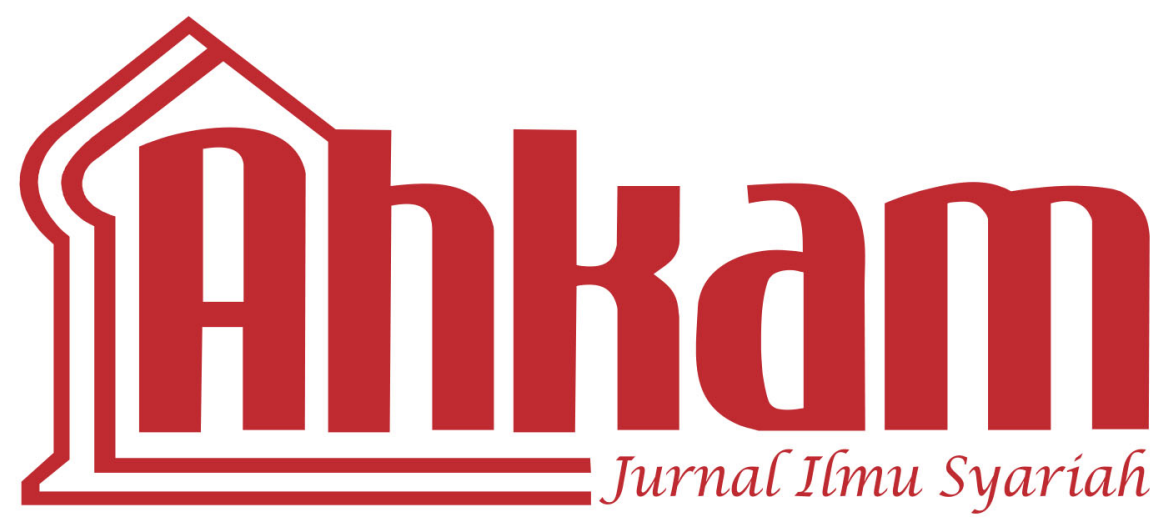

* Herdi Sahrasad \& Al Chaidar

Indonesian Terrorist, ISIS, and Globalization of Terror: A Perspective

* Hotnidah Nasution

Implementation of the Principle of Ultra Petitum Partium in Deciding Children Livelihood in Divorce Lawsuit in Religious Courts

* Havis Aravik, Choiriyah \& Saprida

Critical Study on the Legal Thinking of Muhammad Shahrur

* Nita Triana

Urgency of Arbitration Clause in Determining the Resolution of Sharia Economic Disputes

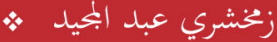

أهمية قوانين المصارف الشرعية في إنلدونيسيا (نظرية التقسير الموضوعى)

* Arrisman

Islamic Law And Business Ethics: Case Study of Forest Fires for Clearing the Lands 


\section{Mhliam}

Volume 18, Number 1, 2018

EDITOR-IN-CHIEF

Khamami Zada

EDITORS

Fathudin

Maman R Hakim

Windy Triana

Nur Hidayah

Ahmad Bahtiar

INTERNATIONAL EDITORIAL BOARD

Tim Lindsey (University of Melbourne Australia)

Nadirsyah Hosen (Monash University Australia)

Ahmad Hidayat Buang (Universiti Malaya Malaysia)

Raihanah Azahari (University Malay Malaysia)

Mark Elwen Cammack (Southwestern University)

Razeen Sappideen (University of Western Sydney)

Carolyn Sappideen (University of Western Sydney)

Nik Ahmad Kamal bin Nik Mahmod (International Islamic Universiti Malaysia)

Ahmad Tholabi Kharlie (UIN Syarif Hidayatullah Jakarta)

Muhammad Atho Mudzhar (UIN Syarif Hidayatullah Jakarta)

Masykuri Abdillah (UIN Syarif Hidayatullah Jakarta)

Muhammad Amin Suma (UIN Syarif Hidayatullah Jakarta)

M. Arsykal Salim GP (UIN Syarif Hidayatullah Jakarta)

Asep Saepudin Jahar (UIN Syarif Hidayatullah Jakarta)

ASSISTANT TO THE EDITORS

Kamal F. Musa

Erwin Hikmatiar

ENGLISH LANGUAGE ADVISOR

Bradley Holland

Umi Kulsum

ARABIC LANGUAGE ADVISOR

Amany Burhanudin Lubis

AHKAM has been accredited based on the determination of Director General of Research Reinforcement and Development, Research, and Technology Ministry of Higher Education of Republic of Indonesia, No. 36/a/E/KPT/2016 (valid until 2021). 
AHKAM Jurnal Ilmu Syariah (ISSN: 1412-4734) is a periodical scientific journal published by Faculty of Sharia and Law of Syarif Hidayatullah State Islamic University Jakarta in collaboration with Indonesian Scientist and Sharia Scholar Association (HISSI). This journal specifically examines the science of sharia and obtains to present various results of current and eminence scientific research. The administrators receive articles as contributions Sharia and Islamic law disciplines from scientists, scholars, professionals, and researchers to be published and disseminated.

\section{EDITORIAL OFFICE:}

Fakultas Syariah dan Hukum UIN Syarif Hidayatullah Jakarta

Jl. Ir. H. Juanda 95 Ciputat, Jakarta 15412

Telp. (+62-21) 74711537, Faks. (+62-21) 7491821

Website: http://journal.uinjkt.ac.id/index.php/ahkam/index

E-mail: Jurnal.ahkam@uinjkt.ac.id 


\section{Table of Contents}

1 Herdi Sahrasad \& Al Chaidar

Indonesian Terrorist, ISIS, and Globalization of Terror:

A Perspective

23 Hotnidah Nasution

Implementation of the Principle of Ultra Petitum Partium in Deciding Children Livelihood in Divorce Lawsuit in Religious Courts

43 Havis Aravik, Choiriyah \& Saprida

Critical Study on The Legal Thinking of Muhammad Shahrur

65 Nita Triana

Urgency of Arbitration Clause in Determining The Resolution of Sharia Economic Disputes

89

زخشري عبد المجيد

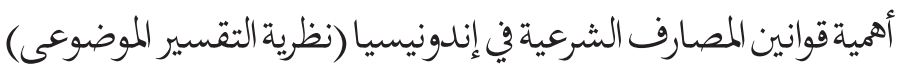


109 Arrisman

Islamic Law and Business Ethics: Case Study of Forest Fires for Clearing The Lands

125 Abdulmajeed Hassan-Bello

Riba and Islamic Banking, Examining the Practices of Jaiz Bank PLC, Nigeria

155 ISNaWATI Rais

Marriage Dispensation due to Extramarital Pregnancy: The Study on the Decision by the Religious Court of South Jakarta (2010-2011)

177 HaMZAH

Zakah Empowerment Optimization Through Baitul Ikhtiar Cooperation as an Effort in Poverty Alleviation in Bogor Regency

201 Abdul Muta'Ali

Israel and Palestine Conflict from Linguistics and Figh

Siyasah Perspective

219 Susiknan Azhari

Tracing the Concept of Fajr in the Islam Mosaic and Modern Science

233 Ahmad Sholihin Siregar

The Construction of Āyātul Aḥkām (Constructing the Selection Bases of Āyātul Aḅkàm) 


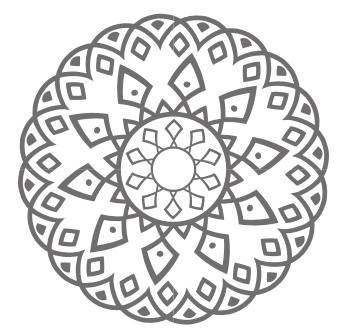

\title{
Riba ANd Islamic Banking, Examining the Practices of Jaiz Bank PLC, Nigeria
}

\author{
Abdulmajeed Hassan-Bello
}

\begin{abstract}
Abstrak: Paper ini mendiskusikan riba, bunga dan alterbatif Islam terhadap perbankan konvensional. Fitur unik perbankan Islam adalah paradigman profitloss sharing, yang utamanya didasarkan atas kontrak Islam beruapa mudharabah dan musharakah. Namun, Bank Islam juga dikritik karena tidak menerapkan prinsip mudharabah secara benar, dimana bank-bank Islam ingin mengambil bagian dalam pembagian keuntungan namun mereka memiliki tingkat toleransi yang rendah terhadap resiko. Studi ini akan menganalisa Jaiz bak plc, bank Islam pertama di Nigrua, sebagai sebuah studi kasus konsep perbankan syariah di negeri ini. Sebagaimana bank-bank Islam di banyak negara lain, Bank Islam Jaiz telah menarik minat pelaku perbankan dimana bank-bank konvensional beroperasi. Sesungguhnya, tantangan yang dihadapi bank-bank Islam adalah keragaman pendapat di kalangan sarjana syari ah, apakah sebuah praktik atau produk, sesuai Syari' ah. Oleh karena itu, paper ini berkesimpulan bahwa melalui pelarangan riba, Islam ingin membangun sebuah sistem ekonomi dimana semua bentuk ekspoitasi dihilangkan. Kesulitan dalam memahami larangan riba ini berasal dari kurangnya penghargaan terhadap kesluruhan nilai-nilai Islam. Oleh karena itu, masa depan bank-bank Islam tergantung tidak hanya pada invetasi di produk-produk baru tetapi juga dalam memenuhi ajaran agama para pemangku kepentingan Bank-bank Islam.
\end{abstract}

Kata kunci: riba, bunga, profit-sharing, joint-venture 
Abstract: This paper discusses the debate over riba, interests and Islamic alternative for conventional banking. A unique feature of Islamic banking is its profit-and-loss sharing (PLS) paradigm, which is predominantly based on the mudarabah (profit-sharing) and musharaka (joint venture) concepts of Islamic contracting. However, Islamic banks are also criticized for not applying the principle of mudaraba in an acceptable manner, where banks are eager to take part in profit-sharing but they have little tolerance for risk. This study will analyses Jaiz bank plc, the first Islamic bank in Nigeria, as a case study of Islamic banking concept in the country. As Islamic banks in many other countries, the Jaiz Islamic Bank seem to attract a fraction of the business of financial transactions where conventional banks operate. In fact, the challenge facing Islamic banks is the diversity of opinion among the Sharia scholars, whether the particular practice or product, is Sharia compliant. The paper therefore, concludes that, by prohibition of riba, Islam wishes to establish an economic system where all forms of exploitation are eliminated. The difficulty to understand the prohibition comes from lack of appreciation of the whole complex of Islamic values. Thus, the future of Islamic banks depends not only upon investing in new products but also upon the satisfying the faith of the stakeholders.

Keywords: riba, interest, profit-sharing, joint venture

$$
\begin{aligned}
& \text { ملخص: ناقش هذا البحث علي الجدل حول الربا والمصالح والبديل الإسلامي للبنوك التقليدية. }
\end{aligned}
$$

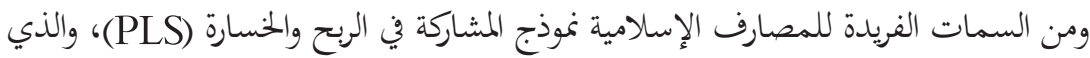

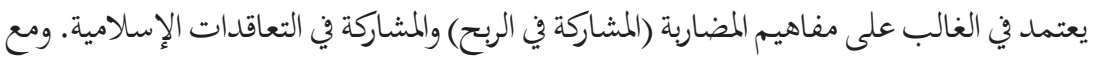

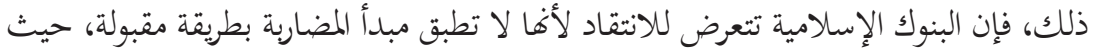

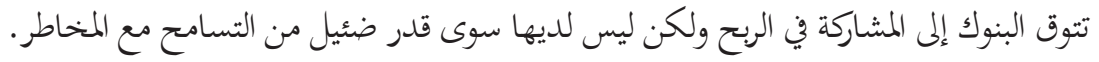

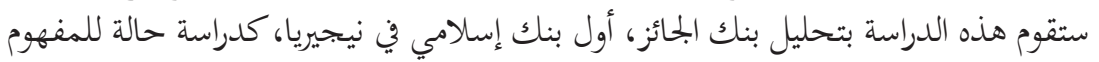

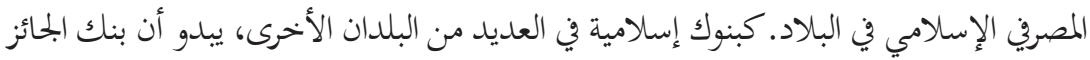

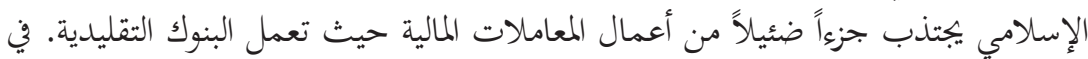

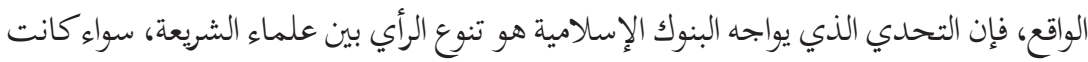

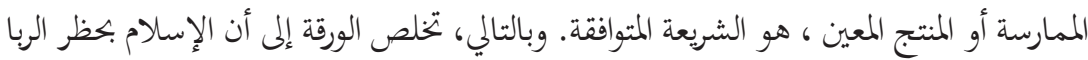

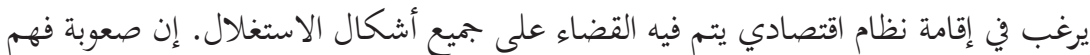

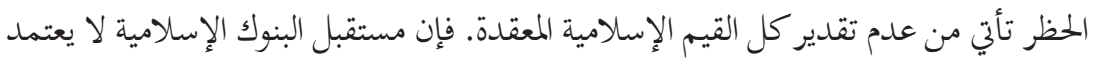

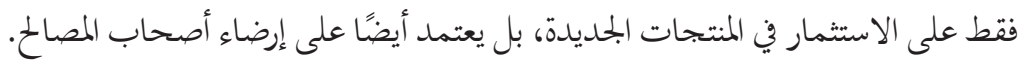

$$
\begin{aligned}
& \text { الكلمات المفتاحية: الربا، الفائدة، المشاركة في الربح، المشروع المشترك }
\end{aligned}
$$




\section{Introduction}

There are arguments for and against the permissibility of Islamic Banks. Critics of Islamic banking argue: how could Islamic banking work when interest (riba) is prohibited in Islam? Those in favour of Islamic banking argue that there are certain ways in which Islamic banks can operate without violating the rules of Sharia. Islamic bank is commonly defined as a form of banking which operates without the norm of interest (Aqdas, 2009). Thus, it is an institution that mobilises financial resources and invests them in an attempt to achieve predetermined Islamic acceptable social and financial objectives. Mobilisation and investment of funds should be conducted in accordance with the principles of Sharia. As a concept, it is comparatively of recent origin. It is only during the last fifty years or so that efforts have been made to develop Islamic banking. It is interesting to note that it is not only the Islamic Development Bank at Jeddah but also the IMF and the World Bank that promote the cause of Islamic banking (Aqdas).

By its definition, structure and functions, a bank cannot exist without interest. These two concepts are too intertwined to be separated. Because of the inseparability between a bank and the norm of interest, it can be concluded that Islamic banking is a mythical and a contradictory concept. If the objective is to abolish interest, the entire banking system will have to be scrapped altogether. In other words, if the foundation of the banking superstructure, namely the norm of interest has to be eliminated, the entire superstructure would have to be dismantled (Aqdas). Minority opinions permitting modern forms of interest have surfaced from time to time, and they were occasionally championed by holders of highly respectable (though, often politically appointed) religious posts (El-Gamal, 2003:1-34). Nevertheless, there exists Islamic banking which offers Sharia compliant finance (Zaman). Though in most Islamic countries where Islamic as well as conventional banks operate, the Islamic banks are relatively very small, and command even small market share. This is not that majority of the Muslim citizens are ambivalent about Islam, but they do not either believe in the permissibility of Islamic banking, or that the banks do not serve their needs (Zaman, 2008:1-15). This paper will critically analyse the deliberation on the permissibility of Islamic Banks. It will examine 
controversies over the Islamic banking in Nigeria, therefore, reaching a conclusion on its attitude and opinion towards Islamic Banks.

\section{Islamic Bank Controversies}

Almost all contemporary writings in Islamic Law and/or Islamic finance proclaim that Islamic Law (Sharia) forbids interest. This statement is paradoxical in light of the actual practices of Islamic financial providers over the past three decades. In fact, the bulk of Islamic financial practices formally base rates of return or costs of capital on a benchmark interest rate. Nevertheless, jurists on the payrolls of Islamic financial providers continue to proclaim all forms of interest as riba, which is subject to the severest Quranic prohibition. As quotations later in this article will illustrate, this dual role of jurists (condemning conventional interest-based financing, while supporting and personally profiting from its "Islamic" twin) is supported through excessively formalistic interpretation of the letter of the Law (El-Gamal, 2).

Minority opinions permitting modern forms of interest have surfaced from time to time, and they were occasionally championed by holders of highly respectable (though, often politically appointed) religious posts. Perhaps the oldest such pronouncement was made by Ebusuud Efendi, the Mufti of Istanbul between 1545 and 1574 C.E., and holder of the title "eyhülislam towards the end of his tenure (ElGamal, 2). Most recently, Sheikh-al-Azhar Muhammad Sayyid Tantawi re-iterated a fatwa (issued opinion in response to a question regarding Islamic Law) that he had issued in 1989, and published in the semiofficial newspaper Al-Ahram, when he was the Mufti of Egypt. This most recent fatwa, carrying the support of the Azhar Islamic Research Institute (IRI) (Majma' al-Bu'th al-Islamiyyah) as well as Tantawi's own, differed little from its predecessors in terms of substance. Indeed, parts of its text seem to be copied verbatim from a book on banking operations published by Tantawi well before the elicitation of this recent fatwa by a member of the IRI, who is also chairman of the board of directors of a bank (El-Gamal, 2).

Fatwa is defined as a legal opinion or decree issued by a Muslim authority (Robinson, 2007: 476). Fatiwa is required to address those matters which are uncertain in Islamic banking activities. For example, most Islamic financial products have been developed through fatwa 
which demonstrates its significance to the industry. In contemporary Muslim societies, one may speak of a number of different Islamic Laws. The lack of a widely accepted contemporary legal codification based on Islamic jurisprudence makes it difficult to speak with any authority regarding the Islamic permissibility or prohibition of any given transaction. Perversely, it is precisely this legal vacuum that allows many individuals to speak with authority regarding those subjects. The source of this authority may be a post to which the speaker was politically appointed, academic credentials sanctioned by a community of scholars, or public support from the "laity" (El-Gamal, 3-4).

Many scholars argue that fatwa resolves controversies and addresses key challenges faced by the Islamic Financial Industry (Malik, Muhammad Shaukat. Malik, Ali and Mustafa, Waqas, 2011). However, at present time there is no ultimate authority or single organisation that governs the Islamic Financial Industry, nor is there any set of rules and guidelines regarding Sharia interpretation (Malik, Ali and Mustafa et al. 240). Thus, the main problem arises, as far as fatwa is concerned, that there remains ambiguity and confusion as to what rule takes precedent. There seems a lack of harmony and uniformity among scholars which encourages scrutiny amid Islamic banking and whether Islamic banking actually works. However, the uncertainty surrounding Islamic banking can be clarified by Sharia scholars through the methodology of fatwa. Fundamentally, fatwa has allowed expert interpretations of Islamic law by scholars who are well equipped with Sharia and finance knowledge. However, having different interpretations on Islamic banking will result in ambiguity amongst Muslims. Where there is ambiguity, the trust of purchasing financial products may be hit with the question of whether it is Sharia compliant (Zaman, 2).

One interesting aspect of the two opinions of Tantawi and the IRI is that they deal exclusively with the relationship between bank depositors and the bank, without addressing the nature of banks' assets. The essence of the fatwa is that bank depositors should be viewed as passive investors, and banks should be viewed as their investment agents. The problem of interest on bank deposits is thus reduced to one of permissibility of pre-specifying the "profits" to which depositors are entitled as a percentage of the capital, instead of specification as a 
percentage of actually realized profits. This constitutes a violation of the classical rules of the silent partnership contracts known as mudaraba or qirad (El-Gamal, 2)? In the conclusions of the Fourteenth Session of Majlis Majma' Al-Fiqh Al- Islami in Doha, Qatar, January 11-16, 2003, the Azhar IRI's characterization of dealings with conventional banks as a legitimate investment vehicle was rejected (El-Gamal, 13).

Islamic banks faced with many controversies and challenges. Those who argue against the Islamic banks, have major concerns in relation to the prohibition of riba their arguments based on the facts that, bank interest is needed to afford savers a safe means of earning a return, and it is necessary for Muslims engaging in business, which is an essential part of the modern system of money and finance without which the whole system will collapse. More importantly, interest is the price of capital. If it is removed there is nothing to establish equilibrium between supply of capital and its demand. Thus, it is necessary for efficient allocation of resources over time as in project evaluation (Siddiqi, 2004:57).

In addition to the above, interest is not the riba prohibited in Islam. It is part of a system entirely different from the one in Arabia of which the prohibited riba formed a part (Rahman, 1964: 1-43). Therefore, Modern bank interest does not violate norms of justice, so there is no moral case against interest. It is not the riba prohibited in Islam. It is paid by rich banks to ordinary people in contrast to that paid by the poor to the rich lenders as in Arabia in olden days. Another difference is that interest is not the riba prohibited in Islam as it is related to commercial loans whereas the former related to consumption loans. In other words, interest is not the riba prohibited in Islam that related to very high rates of compound interest. Thus, it is not the riba prohibited in Islam as bank deposits are not in the nature of loans made to banks but in the nature of capital supplied in mudarabah. Although there has been some academic discussion concerning the exact definition of riba, the generally accepted view of riba is that it extends to all forms of interest. Aqdas says:

The first or the primary myth which has gained common currency throughout the Islamic world is based on gross misinterpretation of the Quranic verses on riba, which have led to the conclusion that riba prohibited in the Quran and the bank interest are identical and as such 
interest must be abolished from all tiers of the economy including banking. The Muslim scholars have never seriously and dispassionately discussed the three basic and inter-related questions. What is riba? What is interest? Are riba and interest co-equal or synonymous? (9).

Linguistically, the term interest is not the riba prohibited in Islam as it is only a predetermined rate of profit that the bank agrees to pay as an agent of the depositor who entrusted to it the task of profitable employment of the deposited capital (Siddiqi, 58).

\section{The Real Meaning of the Term Riba}

Linguistically the word riba means to increase, to grow, to exceed, to be more than. In Sharia meaning "riba" is a term that is used when two parties exchange item of same kind, and in return one party received extra (or in excess) of what he gave. A simple example is when gives 100 units of Gold and received 120 units of Gold in return. The extra or excess 20 units are considered "riba". The most common application of riba is on monetary transaction relating to "loans" and "credits". A simple example of loan is when Lender gives $\$ 1000$ to a Debtor with an agreement that Debtor will return $\$ 1200$ on specified date. Hence, the Lender will receive extra $\$ 200$ (either as his service fee, rent, income, or reward for lending money for stated time period). This extra $\$ 200$ is absolute form of riba in Sharia (Razi, 2008: 18). Similarly, other financial transactions involving riba, such as advancing money on interest, keeping deposits in a bank for the sake of earning interest, or getting concessions in rates of goods or commodities against advance payments of price, mortgaging and utilizing an income-yielding property against a certain sum, to be returned in full when the property is redeemed and investing money in a trade against a predetermined and fixed rate of profit-are all forbidden transactions because they involve riba in some form or the other. And the person doing any of these transactions invariably pay $\mathrm{X}$ amount of money, but in return gets $\mathrm{X}+$ more back (without profit and loss sharing).

Islamic Sharia doesn't limit "riba” application to Loan or financial transaction. In fact the canvas of riba is spread across larger transactions involving any exchange of items between two parties, as far as the items are of same kind, and one item is exchange for other for either 
more or less (Razi,18). Majority of jurists stated two types of riba in transactions:

\section{Riba Al-Nasiab or Riba Al-Duyoon (riba on Debts)}

Riba al-Duyoon is known in the Sharia as riba Al-Nasi'ah. Nasi'ah means delay, defer or wait. It is applied to "money-money exchange"; money is exchanged for money with deferment. Since the verses of Qur'an has directly rendered this type of riba as unlawful (haram), it is called riba al-Qur'an. Similarly, since only this type was considered riba in pre-Islamic era it has earned the name of riba al-jahiliyya Riba al-nasi'ah is the real and primary form of riba that represents predetermined extra amount on deferred payments due to the inability of the borrower to pay its debt on time; i.e., the period for payment by charging more than the principal value. Riba al-nasi'ah underlies most of conventional financial products and services (Alwosabi). The Riba on Credit Transaction, occurred when two items of same kinds are exchanged but one or both parties' delays delivery or payment (Razi, 19).

\section{Riba Al-Fadbl or Riba Al-Buyu' (Riba on Sales)}

(Riba al-Fadl): Selling or exchanging same kind of item with more/less. (e.g. $10 \mathrm{lbs}$ gold exchanged for $12 \mathrm{lbs}$ gold). The excess payment when items of same kinds are exchanged is called Riba alFadl. The Prophet (pbuh) declared that prohibited (Razi, 19). This type of riba gives a more comprehensive implication to riba and is not merely restricted to loans. Riba Al-Buyu' applies to certain types of sales transactions, both immediate exchanges as well as credit exchanges. It is commodity specific and results in what is known as riba Al-Fadhl. Riba on Increase. Riba al-Fadhl is described as an unlawful excess in the exchange of two counter-values where the excess is measurable through weight or measure (Alwosabi, 3). The basis for the prohibition of riba in the exchange of commodities is based on a statement attributed to the Prophet Muhammad. Thus, Just as Islamic law established commodity-specific restrictions on spot transactions, it also placed limitations on the terms on which certain commodities could be traded on a deferred basis (Alwosabi, 2). The prophet Muhammad is reported to have said: 
Sell gold for gold, silver for silver, wheat for wheat, barley for barley, dates for dates, salt for salt - like for like, equal for equal, and hand-to hand (spot); if the commodities differ, then you may sell as you wish, provided that the exchange is hand-to-hand or a spot transaction (Al-Shawkani, 1989: Vol. 3/193).

This hadith created a lot of confusion and many scholars in the past or in recent days expressed their inability to appreciate the reasons and the logic behind the concept of Riba al-Fadhl and its alleged prohibition. Economically speaking it would be irrational and unacceptable to imagine that a person would knowingly commit himself to a bargain whereby he is required to give a superior quality of his commodity to another person for inferior quality of the same commodity. It would indeed be unfair to expect the former to agree to any such deal in spot exchange. Furthermore, there are other hadiths show that the Prophet categorically stated that the question of riba relates to exchanges involving credit and has nothing to do with spot exchanges (Alwosabi, 3).

Thus, the hadiths of riba al-Fadhl, if properly interpreted, serve to clarify two important aspects relevant to the prohibition of riba: one that riba is only applicable to credit dealings and, two, that while dealing with loan transactions, it is absolutely essential that what is returned by the borrower should be identical to the item he borrowed. If one gives on credit gold, then receive back the same gold: the same weight and the same quality; and if gives silver on credit, then receive back the same silver: the same weight and the same quality, because the one who gives more or expects more, then he should know that, that is exactly Riba.' Likewise, if one will sell gold for silver on credit then there is a danger of interest in it (Alwosabi, 3-4).

The translations of the original Arabic text vary so much that the very concept changes. One such example is the translation of the word riba. One of the most popular English-Arabic dictionaries translates the English term usury and interest as riba, (Ba'alabaki, 1985: 47, 1020) though even this word does not convey the full import of the word riba as defined in several verses of the Qur'an. All literature on Islamic banking and finance's report on interest free banking use the term interest. If this translation is correct and conveys the purpose and the spirit behind the prohibition of riba, then there is no need to 
proceed further as this is an injunction, which has to be obeyed. If the word usury is closer to the concept of riba, then nearly every modern government in the world has defined usury as a rate of interest higher than the prevailing bank rate by a prescribed percentage and has treated it as an offense, punishable by law. The word usury also does not convey the full import of the qur'anic term riba (Akhter, 2010).

However, the word 'riba' means 'increase' which corresponds to the word 'interest' as defined by Webster's New World Dictionary. In both cases the increase refers to the amount beyond what is owed. Thus, the strictest interpretation that can be given to the word riba is that it means interest-an amount, or rate, due above the principal of a loan. The word riba, however, is commonly translated as usury which is defined by Webster's Dictionary as "an excessive or unlawfully high rate or amount of interest." Thus, the fundamental aspect of the controversy about the doctrine of interest in Islam is whether the rate of interest is zero, in which case riba is interpreted to mean interest per se, or whether a positive rate of interest is permissible, in which case riba is interpreted to mean usury (Noorzoy, 1982: 3-17).

However, the connotation of riba is not strictly identical with "interest," as commonly understood. But for lack of a better word "interest" may be used as a rough equivalent. In fact, any sum stipulated to be received or given over and above what one advances or receives as a loan is "interest, whether the dealing is with an individual or a bank or a society or a post office or any other organization. "Interest" is not confined to money. It extends to any commodity which is given as a loan with condition that it will be returned with an agreed excess (Farid., 1969: 115).

\section{Financial Products of Islamic Banks}

Although there has been some academic discussion concerning the exact definition of riba, the generally accepted view of riba is that it extends to all forms of interest. The financial instruments used by the Islamic Banks are numerous. Islamic banking transactions, therefore, are structured around the concept of profit-and-loss sharing which utilize the funds at risk on a shared basis between the parties. This unique feature used mainly by Islamic banks apply to several financial products and transactions. In theory, profit-and-loss sharing (PLS) 
ensures that an Islamic bank operates with dual motives: obtaining a profit while maintaining certain social and religious standards (Taylor, 2005: 421).

A unique feature of Islamic banking is its profit-and-loss sharing (PLS) paradigm, which is predominantly based on the mudarabah (profitsharing) and musharakah (joint venture) concepts of Islamic contracting. Under the PLS paradigm, the assets and liabilities of Islamic banks are integrated in the sense that borrowers share profits and losses with the banks, which in turn share profits and losses with the depositors (Chong and Hua Liu, 2008: 1-39). Thus, Islamic banks are theoretically better poised than conventional banks to absorb external shocks because the banks' financing losses are partially absorbed by the depositors. Similarly, the risk-sharing feature of the PLS paradigm, in theory, allows Islamic banks to lend on a longer-term basis to projects with higher risk-return profiles and, thus, to promote economic growth. The PLS paradigm, moreover, subjects Islamic banks to greater market discipline. Islamic banks, for example, are required to put in more effort to distinguish good customers from bad ones because they have more to lose than conventional banks. The banks also need to monitor their investments and borrowers more closely to ensure truthful reporting of profits and losses. Islamic bank depositors, furthermore, are required to choose their banks more carefully and to monitor the banks more actively to ensure that their funds are being invested prudently. Therefore, a primary advantage of PLS banking is that it leads to a more efficient allocation of capital because the return on capital and its allocation depend on the productivity and viability of the project. In practice, however, Islamic banks as practiced today, tends to deviate substantially from the PLS paradigm (Chong and Hua Liu, 3).

The pure Islamic modes of finance under Islamic banking system are Musharakah and Mudarabah based on profit and loss sharing. But these two modes of financing have contributed very less in total financing done by Islamic banks. In 2008 in Pakistan the Islamic banks allowed only $2.3 \%$ of their total financing under the mode of Musharakah and Mudarabah while 92\% under Murabahah, Ijarah and diminishing Musharakah which is based on the mutually agreed fixed return corresponding to the fixed interest rates system under the conventional banking system (Shah, et al., 2012: 1018-1026). Therefore, Islamic 
banks have acknowledged the existence of other financing contracts that are not strictly profit-and-loss sharing in nature. Such financing contracts, for example, may be based on murabahah (cost plus), ijarah (leasing) and salem (advance payment) and qardh al-hassan (benevolent loan) concepts (Siddiqi, 70).

Bai Salam is a form of forward contract when the price for an asset is paid upfront at the time of the contract for an asset or commodity to be delivered later. It can also be defined as the sale where the Asset/ Commodity is delivered on a deferred basis in exchange for the Price be paid immediately. This is different from the idea of murabahah where the Price is paid of deferred basis but Asset is delivered immediately (Al-Zaabi, Obaid Saif, 2010: 92-122).

Wadiah is a non-interest bearing demand deposit (checking account) similar to the ones offered by commercial banks around the globe (although since 1980s, a small interest is paid on this account). It is also a non-interest bearing savings deposit account, but with a promise of giving hiba (gift) whenever the bank has "profits" to share! In practice though, Islamic Banks claim to offer " $h i b a$ " which are a tad higher than the interests on savings account in conventional banks, to attract deposits. In practice, ordinary depositors get nothing and accept that as will of God (Zaman, 8).

The simple mudarabah contract provides for a once for all fixing of the ratio in which the entrepreneur will share the profits realized on the use of the capital provided by the bank for a particular project. It also envisages a single ratio of profit-sharing irrespective of the volume or percentage of actually realized profits. Theoreticians have suggested that the incentive of the working partner, the entrepreneur, can be boosted by raising the ratio of sharing in its favor as the rate of profit per unit of capital rises beyond a certain level (Elias, Kazarian, 1991: 118-130). In other words, a graded scale of ratios of sharing may be more conducive to higher efforts and better performance, resulting in higher productivity that is a social good besides being advantageous to both parties to the contract. We do not have any evidence as to whether the idea has been put to practice or not (Siddiqi, 71).

Mudarabah contract does not provide for a collateral as the return of capital is not guaranteed but contingent on success of the enterprise financed. However the working partner does become liable if and when 
it violates the terms of the contract. It also becomes liable in cases of proven negligence or deliberate mismanagement. Could a collateral be demanded in view of these possibilities, to be invoked in these eventualities only? The idea is yet to be examined, but many Iranian banks are reported to demand collaterals against financing based on mudarabah or musharakah. (Ali, Yasseri, 2002:165) In principle, entrepreneurs being financed on the basis of mudarabah or musharakah cannot be obliged to guarantee a positive return to the financing bank irrespective of the actual outcome of the enterprise. This principle is observed everywhere except in Iran. But this practice of guaranteeing a return is not recognized in Iranian law and the Iranian central bank actually penalizes such a practice (Yasseri, 165-166).

Mudharabah (profit sharing) account is a form of time deposit that cannot be withdrawn before the contractual time is elapsed. The bank as the intermediary (mudharib) takes no risk when it lends money to the borrowers. The borrowers sign contracts that specify the principal amount borrowed and how much would be paid back, all predetermined. Since usually the "cost" of the loan is collected when the loan is given, i.e., the amount of the loan minus the "cost" is advanced, usually such loans are more expensive to the borrower than the ordinary commercial loans offered by conventional banks! If the borrower defaults on the loan, the loss is borne by the depositors to the bank. If the loan is repaid early, the borrower does not receive any part of the "cost" that the bank collected at the origination of the loan! (Zaman, 8)

Murabahah (cost plus) transactions, a very profitable business for Islamic bank is no different in character than that of a finance company (Zaman, 8). Murabahah, as practiced by Islamic financial institutions, is re-sale of a commodity with a mark-up on purchase price. Alternatively we can describe it (as cost-plus). The financing bank sells to a customer the commodity the customer needs and the customer undertakes to pay the (higher than current market) price at a future date. The bank purchases the desired commodity only after getting a commitment from the customer to buy it. Part of this commitment is the price to be paid by the customer which is higher than the market price at which the bank buys it, by a certain amount or percentage. The contracted price cannot be increased even if there is a delay in payment by the 
customer. The customer's obligation to pay is not affected by what becomes of the thing purchased. For example, if it was raw material purchased to manufacture something and sell at a profit, but there is a loss in the business enterprise, the customer is still bound by the contract to pay the price at the agreed time. The price owed to the financier is treated as a loan would have been treated. The debt arising from a credit purchase, as in the current practice of murabahah, and the debt arising from borrowing cash are at par, insofar as the obligation to repay is concerned (Siddiqi, 72)

Murabahah financing leaves the entire results of the use of the commodity financed in productive enterprise for the user, the owner of the enterprise. It is the one to bear losses, if any, and it is the one who owns all the profits. The financier has no share in the profits of a murabahah-financed enterprise. That sounds good for the incentive to work and manage the enterprise to the best of one's capacity. No agency problems and no moral hazard, as we encountered in the otherwise superior profit-sharing finance (Siddiqi, 72).

Ijarah in classical Islamic Jurisprudence is sale of benefits, generally of a durable good. Its modern equivalent is leasing. Just as murabahah/ bay'mu'ajjal has been adapted as a mode of financing the acquisition of goods, machinery, equipment, etc., leasing is used by Islamic financial institutions for enabling customers to use durable goods, equipment in productive enterprises without having to buy them. One can distinguish between operational lease in which there is no obligation of the lessee to buy the thing leased, and the lessor is responsible for its maintenance and insurance, and financial lease. A financial lease ends in the lessee acquiring the thing leased, generally at a nominal price and makes him/ her responsible for insurance and maintenance (Siddiqi, 77).

In other words Ijarah (leasing) or ijarah waqtina (lease and purchase), is another way of enriching the Islamic Bank at the cost of the borrower. The lessee cannot refinance or change the contract in view of changes in the market conditions. Any break in the contract goes in favor of the Islamic bank. Thus, the lessee can lose the equity in the property after paying payments for a number of years, if for some reason s/he can no longer honor the contract! (Zaman, 9.) Qardh alhassan (goodwill loan) is given in good faith-the borrower is obliged to pay back the amount lent only, without any obligation to pay 
anything extra. It is quite obvious that not many loans would be given by a financial institution that is open for business of making money (Zaman, 9).

Musharakah, or shirkah, (joint venture) is partnership. It envisages both or all parties to the contract putting in some capital. Each partner has a right to participate in decision-making, i.e. management of the enterprise. But there is no bar on this right not being exercised or being transferred to another partner. This provision makes musharakah contract flexible enough to be adapted to financial relationships. Profitsharing rules are subject to negotiation but have to be unanimously adopted. However when adapted to be applicable to joint stock companies with very large number of partners (share-holders), this provision of classical fiqh got translated into majority rule of decision making. As regards losses, they are defined as erosion of capital and have to be borne in proportion of capitals put in. No negotiations are allowed. These details technically belong to a particular type of partnership as defined in classical Islamic Jurisprudence shirkah 'anan (Siddiqi, 69-70).

Musharakah (joint venture) in which an Islamic Bank and clients jointly finance a venture by issuing 'participation certificates' that can be bought and sold in the market. This type of joint venture is commonly known as sukuk. Sukuk are investment certificates. Sometime they represent 'ownership' in the assets underlying the issue. Those with variable returns are based on mudarabah or musharakah. More popular are those with pre-determined, fixed incomes. The simplest of these is the one based on ijarah, i.e., lease or hire. A building (or an oil tanker) is purchased and rented out, the money capital for the purchase having been mobilized by selling certificates. Owners of these certificates would be entitled to receive a portion of the rent income. These certificates can be traded in the market (Siddiqi, 2006: 1-48).

There are sukuk based on salam or istisna contracts. Also there are hybrid issues whose underlying assets are mixtures of these. Murabahah receivables being debt obligations are not considered fit for sukuk issue. But they have been accepted in such a mixture as long as they are in a minority. The sukuk market has recently gotten a boost by the entry of the Islamic Development Bank with its first issue, which is a hybrid that includes murabahah receivables (Siddiqi, 11). In case of ijarah bonds, a 
predetermined return can be promised on the basis of the lease contract already in effect. In case of the later also it is possible to do so if sale of the goods involved is allowed before taking possession, and, in effect, before their production. The case of murabahah receivables is, however, different. They are debt obligations that can be exchanged only at par value. They do not qualify as assets on the basis of which tradable bonds can be issued. Since this implied keeping the huge volume of murabahah receivables illiquid, a way around the disqualification was found by issuing of hybrids in which murabahah receivables form a minority. This brings these debt obligations into the Islamic financial markets everywhere. Previously they were being traded only in the Malaysian market. But it is not a 'solution' guaranteeing readily available liquidity to debt obligations, as their volume may be too large to be accommodated as minority components of hybrid sukuk (Siddiqi, 11).

As practiced, a series of contracts have to be stitched together for launching sukuk. A minimum of three contracts form the core of the structure to which two more are added because of the need to have a 'special purpose vehicle (spv)', which is generally a limited liability company, to handle an issue. The need for guarantee may bring yet another contract, and so on. The three contracts which form the core are: (1) between the owner of an asset and the certificate holders (investors) who purchase the asset from its original owner, thus providing the finance, (2) between the user of the asset who takes the asset on lease from its(new) owners, the certificate holders, and pays rents that are the source of investor's income, and (3) the institution intermediating between the two, first in transfer of ownership and then in effecting a lease agreement, collecting the rent and distributing it as returns on investment to certificate holders. (As we see later, in general the original owner of the asset and the user/lessee are the same entity). It is the financial intermediary that mobilizes funds by selling certificates, acquires the asset and puts the asset on lease. This last mentioned act generates the revenue from out of which come the returns earned by the certificate holders and profits/fees earned by the financial intermediary. Changing perceptions about the future prospects cause the market values of these sukuk to vary from time to time creating capital gains and bringing in the speculators (Siddiqi, 12).

Sell and buy back became involved in this process for a number 
of reasons. One of these reasons could have been the need for an asset to be there before certificates/sukuk based on it could find customers so, the 'special purpose vehicle (spv), a financial intermediary, acquires ownership of the asset in order to be able to sell certificates based on the ownership). Yet, another could be the fact that finance obtained through sale of sukuk was intended for development related to the very asset that formed the basis of those sukuk. The point worthy of note is that the buyback contract does not belong to the three core contracts mentioned above. (Meaning, the lessee/user need not necessarily be the original owner) It is necessitated by other needs, including the need of the seller, the original owner, to have continuous control over the asset. That makes sale lease-back sale-back the standard in the current practice of sukuk based on ijarah (Siddiqi, 12).

Thus, the sukuk play a positive role in mobilization of savings on a vast scale. They benefit investors as well as those who have projects to finance that bear the promise of eventually generating sufficient revenue to meet the costs yet leave a surplus (Siddiqi, 13). However, there are a number of problems with the conventional bonds:

First, the return paid to the bondholders bears no relation with the actual productivity of the capital raised through the bonds. Second, no real asset may correspond to the financial asset called bond. Third, separation of return from actual outcome opens the door to corruption as it misaligns the interests of the financiers and the project owners, i.e., the business that is being financed. Fixed as well as variable income sukuk share the first feature with bonds. They may not share the second feature, depending on the nature of underlying assets. It is an advantage for sukuk to correspond to real assets. This is in consonance with the characteristics of Islamic finance to integrate the financial sector with the real sector. This feature of Islamic finance contributes towards greater stability. But the first feature, that returns to sukuk bear no relationship with actual productivity of the funds raised through their sale, is a disadvantage (Siddiqi, 14). Cash or money capital itself has no productivity. It is the goods and services acquired by spending it that are productive, though this productivity is surrounded by uncertainty. Should sukuk be representing goods and services they would represent something productive, capable of yielding a return. If the return to sukuk is a function of the actual productivity, it may be characterized as a 
fair arrangement. If the return is independent of the actual productivity its fairness is not assured. Even when no production takes place, and therefore there is no profit to be distributed, sukuk holders will be given the returns written into the contract. This arrangement makes the users of real assets bear all the uncertainty involved in productive enterprise. They have to bear all the losses (Siddiqi, 14).

A system in which those who supply money capital are assured of profits but those who use money capital, converting them into goods and services needed in productive enterprise, bear all losses if there are losses, is not just and fair. Justice and fairness requires that uncertainties attending upon productive enterprise be shared. Justice and fairness require that losses, if and when they occur due to these uncertainties, be borne by those who claim the profits when there are profits. If the arrangements under which productive enterprise takes place are not fair the social fabric is damaged. In the long run an unfair and unjust arrangement produces conflicts and disrupts peace (Siddiqi, 14).

Apparently, the market for sukuk mushroomed to around $\$ 41$ billion (Raphaeli, 2011) fueled by Middle Eastern oil money that is being invested in building booms and other infrastructure. It is not clear how returns on such instruments are determined but, the returns are predetermined nonetheless (Siddiqi, 16). If the past is any indication, it would be based on returns from similar instruments issued by "nonIslamic" entities and would simply be labeled as profit sharing. It would be interesting to watch what happens when an Islamic Bank fails to meet its obligations on sukuk to the investing public (Zaman, 9). In practice, most of the Islamic banks are operating parallel to conventional banking. Most of the Islamic banks have taken up the mode of financing on fixed return basis, not on profit and loss sharing. The basic and foremost characteristic of Islamic Banks is that, instead of a fixed rate of interest, it is based on profit and loss sharing. The contention that Islamic financing is based on PLS is not supported by any quotation from Quran and Sunnah For instance a customer wants to buy a car worth $\mathrm{N} \mathrm{1,000,000.00} \mathrm{The} \mathrm{bank} \mathrm{buys} \mathrm{the} \mathrm{car} \mathrm{in} \mathrm{its} \mathrm{name}$ and resells the same to the customer at N 1,200,000.00 and he pays N 100,000.00 per month for 12 months. Till he paid 20\% extra and the bank makes him to believe that the additional $20 \%$ is not interest! (Donald Jnr, 2011). What do we call it, if not interest? 


\section{Jaiz Bank PLC, Nigeria}

In Nigeria, the practice of Islamic finance was introduced in 1992 by the defunct Habib Bank following the promulgation in June 1991, of the Banks and Other Financial Institutions Decree (BOFID - as amended) by the then Military President Ibrahim Badamasi Babangida. Section 66 of that law introduced the term "Specialised Institutions" for which Islamic finance is a model. Other forms of specialized institutions recognised by BOFID include: Nigerian Industrial Development Bank, Nigeria Agricultural and Corporative Bank, Nigerian Export and Import Bank, Nigerian Bank for Commerce and Industry, the Urban Developmental Bank, Federal Mortgage Bank, Microfinance banks, Mortgage banks, Community Banks and such other banks as may be designated from time to time (Oshodi, 2014).

Profit and Loss Banking has always been the interpretation and understanding of Non-Interest Financial Services in Nigeria. When the CBN granted an Approval-in-Principle Licence to Jaiz International Bank PLC in 2004 while Chief Joseph Sanusi was the CBN Governor, the licence was issued for it to carry on business as a Profit and Loss Sharing Bank. Curiously, not much was heard of the Bank till January 13, 2011 when the Central Bank of Nigeria issued a Framework on Non-Interest Financial Institutions (NIFI). This was followed with the then CBN Governor's, Sanusi Lamido Sanusi, (now Emir of Kano) announcement on Monday, June 20, 2011, at a Conference on Islamic Banking in Dakar, Senegal, that it had issued Jaiz International Bank PLC an Approval-in-Principle as the "first Islamic Bank in the country" (Eyieyien, 4).

The critics of Islamic bank in Nigeria alleged that Jaiz Bank was unable to operate as a Profit and Loss Sharing Bank not because there was no Islamic Banking Guideline but simply because it was unable to raise the minimum capital requirement of N25Billion. Thus, he accused the CBN Governor to have lowered the capital requirement for Islamic Banks to just N10Billion to achieve "National Bank" status as against the N25Billion it stipulated for Deposit Money Banks (Eyieyien, 2011:1-7).

Thus, by BOFIA stipulations, in the view of critics, Islamic banking is illegal because the Central Bank of Nigeria has no power to make laws or narrow Non-Interest banking to Sharia principles; stressing that 
'CBN should sponsor a bill in the National Assembly if it must add anything to the extant laws. It cannot use a framework to change the law. It is not due processes. He said though not against Islam, his fears was that the average Nigerian who does not understand the law, only knows at the moment that CBN want to Islamize Nigeria. He believes that, by the proposed plan to establish the CBN Sharia Council, which he presumes would obviously comprise only Muslims, the CBN would be contravening the Federal Character Principle entrenched in Section 14(3), which states that 'The composition of the Government of the Federation or any of its agencies and the conduct of its affairs shall be carried out in such a manner as to reflect the federal character of Nigeria and the need to promote national unity, and also to command national loyalty, thereby ensuring that there shall be no predominance of persons from a few states or from a few ethnic or other sectional groups in that government or in any of its agencies (Eyieyien, 4).'

However, Jaiz Bank Plc upgraded to a National operating license in 2016. The upgrade has enabled it to operate in all 36 states of the Federation including the Federal Capital Territory. Consequently, it increased its authorised Share Capital from N15 billion (USD \$47.8 million) to N25 billion (USD \$79.6million). (Note that the exchange rate used was the prevailing rate at the end of 2016.) (Jaiz Bank Plc, 2016)

The bank is a quoted public company owned by over 26,000 shareholders spread over the six geo-political zones of Nigeria. The Bank's balance sheet has grown from N12 billion in 2012 to about N62 billion, with asset financing of over N30 billion. The Bank was created out of the former Jaiz International Plc which was set up in 2003/2004 as a Special Purpose Vehicle (SPV) to establish Nigeria's first full-fledged Non-Interest Bank. It obtained a Regional Operating License to operate as a Non-Interest Bank from the Central Bank of Nigeria on the 11th of November 2011 and began full operations as the first Non-Interest Bank in Nigeria on the 6th of January, 2012 with 3 branches located in Abuja FCT, Kaduna and Kano. The Regional License allowed the Bank to operate geographically in a third of the country. Also, based on recommendations from Islamic Development Bank (IDB), which is also a shareholder of the bank, Jaiz Bank PLC had partnered with Islamic Bank of Bangladesh (IBBL) for Technical and Management Assistance (Jaiz Bank Plc). 
The business potential for a Non-Interest Bank in Nigeria is enormous as such an institution has long been awaited by a population of over 93 million Nigerians representing over $50 \%$ of the country's population of about 183 million. Jaiz Bank's strategic business focus is mainly on retail banking, having due regard to a report published by KPMG in 2006 which estimated the market for retail banking in Nigeria at US\$30 Billion. The Bank nevertheless offers corporate and commercial banking services in addition to its retail product offering. The Bank's retail focus will enable it to service the majority of Nigerians who wish to do away with riba (usury) in their daily activities. The Bank is being positioned to be a national bank offering its services to all regardless of religious beliefs (Jaiz Bank Plc).

Jaiz Savings Account designed specifically to meet the requirements of customers who authorize the Bank to invest their cash deposits. Customers can deposit or withdraw money at any time they wish. The Bank allocates the funds received from the customers to a deposit pool; funds from the pool are invested an ethical and responsible manner. Profit earned is shared at the end of every month between the depositors and the bank based on agreed sharing ration. (Currently 70:30 bank: customer as approved by CBN). This product is ideal for individuals or corporate customers looking for car financing. It enables you acquire a car on the principle of Ijara (lease) for rental payments. Under this arrangement the Bank purchases the car and leases it out to the customer for a period not more than 4 years. After the lease period the customer gets ownership of the car against his initial security deposit (Jaiz Bank Plc).

In addition to leasing of new cars, Jaiz Bank also provides a unique opportunity of leasing second hand vehicles. This feature is designed to enable more Nigerians afford a care of their choice. This lease facility is made available at a minimum-security deposit of $30 \%$. Financing of used cars are subject to a selection criteria. This product is restricted to salary account holders, schools, hospitals and business with active accounts with Jaiz. In addition, Jaiz premium savings account (JAPSA) is an investment product based on the principles of partnership called mudarabah and is offered to our unique and highly valued premium customers. The account allows customers' earn profit at competitive rates on their deposits. The Bank allocates the funds received from the 
customers to a deposit pool. Funds from the pool are invested in an ethical and responsible manner and profit is distributed at the end of every month based on customers account balance at a profit sharing ratio of 50:50 and 60:40, depending on the volume of investment. The minimum deposit for N10, 000,000.00 (ten million naira), while the minimum investment period is 30 days (Jaiz Bank Plc).

Jaiz Salary Current Account is designed for Salary earners to provide easy and convenient access to their funds while enjoying host of other professional services from the bank. Benefits include, Quick and easy processing; Access to the Bank's finance facilities; Instant Verve card issuance; Withdraw cash from all ATM Terminals in Nigeria; Make Purchases via Point of Sales Terminals (POS); Instant transfer; Internet Banking Services; Mobile Banking Services; SMS Banking; Third Party Withdrawal via cheque and Zero COT (Jaiz Bank Plc).

Jaiz Domiciliary Account is tailored to customer that carry out frequent foreign currency transaction, the account is designed to help you conveniently carry out foreign currency transactions from the comfort of your home, office or abroad. The account can be funded in Dollars, Pounds or Euro. Benefits include, Telegraphic Transfer Services and Internet Banking Services. This product is tailored to Corporate and individual that wants periodic and stable return on their investment. The bank will collect deposits from its customers and invest the same in a specific business venture to be agreed with the customer. The bank however acts as an agent to invest depositor's funds in an ethical manner. The bank will indicate the expected profit rate to the customer on the agreed period for the investment. Minimum Investment of N200, 000,000.00 (two hundred million naira only) or its equivalent in any other currency acceptable to the bank. Funds collected from the investor can be deployed towards Investments in transactions permitted under sharia using any of the Islamic finance contracts approved for the bank. Expected rate of return on each transaction is agreed between the parties involved in the transaction before commencing the investment (Jaiz Bank Plc). 


\section{Assessing the Operations of the Islamic Banks}

The review of the financial instruments above lends to an obvious question, in what ways do the so-called Islamic Banks qualify to be called Islamic? Apart from the claims that the Islamic Banks follow Islamic "principles", there is no difference in their operations than the conventional financial institutions, CFI, except for the fact that the Islamic Banks principal thrust is towards maximizing their own coffers at the cost of depositors and the borrowers (Zaman, 9).

It can be demonstrated that the Islamic Banks use religious slogans to misrepresent the common people that these are functioning to promote welfare of the believers. In reality, most of their loans cost lot more than what the conventional banks charge. While the CFI are subject to regulations and are accountable for their actions, the Islamic Banks are probably more prone to corruption and mismanagement, all they need is a review from their Sharia council (in cases where the NBFI are outside the supervision of central banks), that the transactions do not involve dealing with interest rates. The Islamic Banks frequently place their customers' deposits into short term instruments of conventional banks abroad to earn interests so that they can present their own depositors shares of their interest earnings as "profits" and/or, advance hiba (gift) to them! (Zaman, 9)

In other words, the acceptability of the above non-PLS modes of financing, however, have been widely debated and disputed because of their close resemblance to conventional methods of interestbased financing. Many Islamic scholars have warned that, although permissible, such non-PLS modes of financing should be restricted or avoided to prevent them from being misused as a "back door" for interest-based financing (Chong and Hua Liu, 4). The products that modern-day Islamic bankers have created are very similar to conventional products. So similar, in fact, that to an outside observer they could be considered the same. Islamic banks now offer Islamic mortgages, Islamic car loans, Islamic credit cards, Islamic time deposit and guaranteed return accounts, Islamic insurance and some even offer Islamic managed and hedge funds. This point is conceded by Samir Alamad, Sharia, or Islamic law, compliance and product development manager of the Islamic Bank of Britain. "The industry does not want to alienate its products," he says: "They have to be recognisable, produce 
the same outcome as conventional products, but remain within the guidelines of Sharia" (Foster, 2012).

The business operations of Islamic Banks typically work with a supervisory board of religious advisors that review proposed transactions and novel financial structures to ensure that the financial institution's activities avoid violating Sharia principles. Each Islamic banking and finance institution has a Sharia board, usually comprised of between one and three respected Islamic scholars who certify that the Islamic banking and finance institution's products are Sharia compliant (Khan, 817). In theory, the Islamic scholars should be able to clarify Sharia compliant issues contained in Islamic banking products. However, in practice this is currently not the case as many academics have been critical of Sharia boards and the lack of standardisation within Islamic banking (Zaman, 3).

In this context, the biggest problem of the Islamic banking system is that people are not clear about what Islamic banking constitutes (Karbhari, 2004: 524). In this view, the confusion about Islamic banking is caused by the Islamic Sharia Committees' various interpretations of what is and is not Islamic banking. In other words, there is always a possibility that the interpretation by one committee of scholars is different from the interpretation of another committee, which demonstrates a lack of standardisation. The challenge facing Islamic banking is the diversity of opinion among the Sharia scholars (Briault, 2007), due to which leading consumers and investors are uncertain whether the particular practice or product, is Sharia compliant (Zaman, 3).

On the other hand, there are bodies and organisations including the Accounting and Auditing Organisation for Islamic Financial Institutions (AAOIFI) which are trying to resolve the lack of Islamic standardization (Malik, et al., 43) One of the main goals of this organisation is to design and disseminate accounting and auditing standards that can be applied internationally by all Islamic institutions (Sole. 2007:6) The support from the AAOIFI is making much-needed progress to enhance standardisation across Islamic financial institutions which would allow the industry to expand globally. However, these organisations unfortunately have no binding powers to implement their standards on the industry and they merely develop recommendations with insufficient legal backing and compliance to enforce its standards, since they are entirely voluntary (Karbhari, et al., 527). 
Many commentators argue that the idea of Islamic banking is still relatively young, and new circumstances and issues are likely to occur that will result in further clarification, they are of the view that Islamic banking is not yet fully complete. Potential investors and customers need to be aware that in order for the system to adhere to Sharia Principles, it needs more time. As Islamic banking further evolves, it is expected to experience an increase in the standardisation of its concepts and practices (Karbhari, et al., 524). Since the Islamic banking system has recently emerged, the need for Sharia principles are left to Muslim scholars. There is confidence that although there is no agreement between the scholars, at this present time, the need for a consensus will soon be of paramount consideration in the near future, which will grasp widespread acceptance for Islamic banking (Zaman, 4).

The majority of Islamic banking clients are found in the Gulf States and in developed countries. With $60 \%$ of Muslims living in poverty, Islamic banking is of little benefit to the general population. The majority of financial institutions that offer Islamic banking services are majority owned by Non-Muslims. With Muslims working within these organizations being employed in the marketing of these services and having little input into the actual day to day management, the veracity of these institutions and their services are viewed with suspicion. One Malaysian Bank offering Islamic based investment funds was found to have the majority of these funds invested in the gaming industry; the managers administering these funds were non-Muslim. These types of stories contribute to the general impression within the Muslim populace that Islamic banking is simply another means for banks to increase profits through growth of deposits and that only the rich derive benefits from implementation of Islamic Banking principles (Donald Jnr, 9).

Hence, in reality the Islamic Banks as practiced today everywhere, are deposit-taking finance companies if outside the central bank purview. Here in lies their attractiveness to the major financial institutions of the developed West. The potential wealth locked up in oil-rich Gulf States encouraged the conventional banks to enter Islamic finance. HSBC established the Amanah Islamic Finance brand in 1998 and Deutsche Bank, Citi, UBS and Barclays quickly joined the fray, all offering interest-free products for wealthy Arabs (Foster). It is not that the Citibank or HSBC suddenly developed fervor for "Islamic" banks 
and financial institutions. Where else they can find easy way of making money without any risk or responsibility to their clients, and without being subject to regulations. After all, the Islamic Banks have been using their facilities to earn short term income and delve into futures, options, and other speculative transactions! (Zaman, 10). The modern Islamic bankers had a way of dealing with this, one investment banker based in Dubai, working for a major Western financial organisation explains:

We create the same type of products that we do for the conventional markets. We then phone up a Sharia scholar for a Fatwa (seal of approval, confirming the product is Sharia compliant). If he doesn't give it to us, we phone up another scholar, offer him a sum of money for his services and ask him for a Fatwa. We do this until we get Sharia compliance. Then we are free to distribute the product as Islamic (Foster).

Islamic banks are also criticized by some for not applying the principle of mudarabah in an acceptable manner. Where mudarabah stresses the sharing of risk, critics point out that these banks are eager to take part in profit-sharing but they have little tolerance for risk. To some in the Muslim community, these banks may be conforming to the strict legal interpretations of Sharia but avoid to recognize the intent that made the law necessary in the first place (Donald Jnr., 9). The Islamic Banks, as institutions, seem to attract a fraction of the business of financial transactions in countries where CFI are allowed to operate. The total assets of all IBFI are miniscule Siddiqi pointed out that glance at the 2005-2006 Annual Report of the Islamic Development Bank compared to the CFI in the Muslim countries, and compared to some of the regional banks' assets in the US. It will not take long for the Muslims to figure out that the sukuk transactions are nothing more than institutional bonds, but with mismatched risk-return relationship. It appears that no matter how the transactions are structured by the IBFI, as long as these are made into "contract" documents, these are termed as Islamic (Siddiqi, 14).

\section{Conclusion}

By prohibition of riba in Islamic law, Islam wishes to establish an economic system where all forms of exploitation are eliminated, and particularly the injustice perpetuated in the form of the financier being 
assured of a positive return without doing any work or sharing in the risk, while the entrepreneur, in spite of his management and hard work, is not assured of such a positive return. Islam wishes to establish justice between the financier and the entrepreneur. Under these circumstances it is difficult to see how anyone could justify interest in an Islamic society. The difficulty to understand the prohibition comes from lack of appreciation of the whole complex of Islamic values, and particularly its uncompromising emphasis on socio-economic justice and equitable distribution of income and wealth. Any attempt to treat the prohibition of riba as an isolated religious injunction and not as an integral part of the Islamic economic order with its overall ethos, goals and values is bound to create confusion.

It is important to realize that Islamic Banks are engaged in a trade (tijara) that deals with the management of money and financial securities and services, and they do not operate like "money lenders" or "loan sharks." The depositors place their deposits either for a short or a longer period, seeking some returns to offset the loss of purchasing power if kept 'under the mattress', or to augment their future income, while the borrowers borrow to meet the needs for funds for business and/or consumption that are vital to them and are willing to pay a reasonable fee for the service. It should be borne in mind that banking/ financial institutions are only intermediaries and should act accordingly, and that the bank officials must be held accountable for their actions and should be held responsible for willful negligence.

In theory, a unique feature that differentiates Islamic banks from conventional banks is the PLS paradigm. In practice, however, the Islamic banks are not very different from conventional banks from the perspective of the PLS paradigm. It is crucial to remember at all times that the purpose of Islamic Banks is not to "replicate" in an Islamic way, the conventional finance products but to create new financial products which appeal to Islamic Banks and investors, even if this means slower growth. Islamic banks need more experts both in field of Sharia and finance and try to bridge the gap between Sharia scholars and develop a single authority that has the authority to assure that the product provided by Islamic banks is completely in accordance with Sharia rule and regulation. The future of Islamic banks depends not only upon innovating and investing in new products according to the 
demand of the market but also upon the satisfying the faith of the stakeholders.[]

\section{References}

Akhter, Syed Hashim Ali. (2010). "Riba And The Credit Needs of Muslims," available at: <www.muslimpersonalfinance.org/syed-hashim-ali-akhter. $\mathrm{html}>$ accessed 23/02/18

Ali, Yasseri. (2002). 'Islamic Banking Contracts as enforced in Iran', Islamic Banking and Finance: New Perspectives on Profit-Sharing and Risk, Munawar Iqbal and David T. Llewellyn (eds), (Edward Elgar UK.

Al- Shawkani, Muhammad bin Ali. (1989. Nayl al-Awtar. Cairo: Maktabah Dar Tura'ath, Vol. 3

Al-Zaabi, Obaid Saif, (2010) "Salam Contract in Islamic Law: A Survey". In Review of Islamic economics. Vol. 14. No. 2: 92-122

Alwosabi, Mohammed. "The prohibition of riba (usury)". Available at: http://staff. uob.edu.bh/files/620922311_files/Riba.pdf accessed 22/03/2018

Aqdas, A. K. "Islamic banking is a mere myth". September 27, 2009, available at: www.dawn.com/news/881273 accessed (21/04/2018).

Ba’alabaki, Munir. (1985). Al-Mawrid: A modern English-Arabic Dictionary (Beirut: Dar El-Ilm Lil- malayen.

Briault, C. 'London Centre of Islamic Finance?' (2007). "Financial Service Authority," http://www.fsa.gov.uk/pages/Library/Communication/ Speeches/2007/1018_cb.sht accessed 22/07/2018

Chong, Beng Soon and Hua Liu, Ming. 'Islamic Banking: Interest-free or Interestbased?' (2008), 1-39 <http://ac.els-cdn.com/S0927538X08000036- main. pdf?> accessed 13/07/ 2018

Donald Jnr, Kexter E. A. (2011) Sanusi's Islamic Banking: The Untold Truth! http://saharareporters.com accessed 26/07/18

El-Gamal, M. A. "Interest" and the Paradox of Contemporary Islamic Law and Finance". In Fordham international law journal. January 2003 27(1) 1-34 $<$ https://pdfs.semanticscholar.org/8cb7/0cc8baaf911ad52f93222f76e3f049 .pdf> (22/03/2018).

Elias, Kazarian. Finance and Economic Development: Islamic Banking in Egypt (University of Lund, Department of Economics Lund Sweden 1991) at 118-130.

Eyieyien, Eghes. The CBN, Islamic Banking, the law and appropriate regulation of non-interest financial institutions in Nigeria. <https://www.proshareng. com/articl-/6> accessed 19/03/2018

Farid, Malik Ghulam. (ed). The Holy Quran with English Translation \& Commentary (Tilford, Surrey: Islam International Publications Ltd, 1989). 
Foster, John. 'How Shariah-compliant is Islamic Banking?' (2012). http://news. bbc.co.uk/1/hi/business/8401421.stm accessed 13/07/2018

Jaiz Bank Plc. <www.jaizbankplc.com/aboutjaiz> accessed 20/03/2018

Karbhari, Yusuf, Naser Kamal, and Shahin, Zerrin. (2004). 'Problems and Challenges Facing the Islamic Banking System in the West: The Case of the UK. <http://onlinelibrary.wiley.com/store/10.1002/tie.20023/asset/20023_ f606c $2>$ accessed 14/07/ 2018.

Khan, Feisal. 'How 'Islamic' is Islamic Banking? (2010) 817. http://ac.els-cdn.com/ S0167268110001940/1-s2.0-S0167268110001940-/ accessed13/07/ 2018.

Malik, Muhammad Shaukat. Malik, Ali and Mustafa, Waqas 'Controversies That Make Islamic Banking Controversial: An Analysis of Issues and Challenges' (2011). http://www.scihub.org/AJSMS/PDF/2011/1/AJSMS-2-1-41-46. pdf accessed 21/07/ 2018.

Noorzoy, M. Siddieq. (1982). "Islamic laws on Riba (interest) and their Economic Implications," International Journal of Middle Eastern Studies 14, no. 1 (1982): 3 - 17.

Oshodi, RahmanA. “Nigeria:InvestigatingIslamic Financein Nigeria”, 17 April 2014. <http://www.mondaq.com/.../investigating+islamic+finance+in+nigeria> accessed 06/07/2018.

Rahman, Fazlur. 'Riba and Interest', Islamic Studies Islamabad (March, 1964), 1-43.

Raphaeli, Nimrod. (2011). "Islamic Banking - A Fast-Growing Industry". <http:// www.aclu.org/files/fbimappingfoia/20111110/...> accessed 08/07/2018.

Razi, Mohammad (2008) “Riba in Islam," < https://kantakji.com/media/3241/ribain-pdf $\quad$ accessed 25/07/2018.

Robinson, Mairi. (2007). Chambers $21^{\text {st }}$ Century Dictionary (Edinburgh: Chambers Harrap Publishers Ltd.

Shah, Syed Farhan; Raza, Muhammad Wajid; and Khurshid, Malik Rizwan. "Islamic Banking Controversies and Challenges," Interdisciplinary Journal of Contemporary Research in Business. Vol. 3, no. 10, (2012), 1018-1026.

Siddiqi, Mohammad Nejatullah. (2004). Riba, Bank interest and the rational of its prohibition. (Jeddah: Islamic Development Bank, Islamic Research Training Institute.

, "Islamic Banking and Finance in Theory and Practice: A Survey of State of the Art," Islamic Economic Studies Vol. 13, No. 2, (February 2006), 1-48. <www.irti.org/English/Research/Documents/IES/090.pdf> a c c e s s e d 08/07/2018.

Sole J, ((2007). "Introducing Islamic Banks into Conventional Banking Systems" http://www.imf.org/external/pubs/ft/wp/2007/wp07175.pdf accessed 14 /07/2018. 
154 - Abdulmajeed Hassan-Bello

Taylor, J. Michael. "Islamic Commercial Banking - Moving into the Mainstream", Vol. 18, no. 2 (2005).

Zaman, D. "Islamic Law: The Prohibition of Riba". www.academic/edu/32783282 $13 / 07 / 2018$

Zaman, M. R. "Usury (Riba) and the place of Interest in Islamic Banking and Finance", The International Journal of Banking and Finance, 2008/09 Vol. 6. No. 1: 2008: 1-15.

Abdulmajeed Hassan-Bello, Senior lecturer, Department of Religious and Cultural Studies, University of Uyo, Nigeria. Email: boladebello@yahoo.com 


\section{Mhliam}

AHKAM Jurnal Ilmu Syariah (ISSN: 1412-4734/E-ISSN: 2407-8646) is a periodical scientific journal published by Faculty of Sharia and Law of Syarif Hidayatullah State Islamic University Jakarta in collaboration with Indonesian Scientist and Sharia Scholar Association (HISSI). This journal specifically examines the science of sharia and obtains to present various results of current and eminence scientific research. The administrators receive articles as contributions Sharia and Islamic law disciplines from scientists, scholars, professionals, and researchers to be published and disseminated. The article will be situated in a selection mechanism, a review of proved reders, and a strict editing process. All articles published in this Journal are based on the views of the authors, but they do not represent the authors' journals or affiliated institutions.

AHKAM has been accredited based on the determination of Director General of Research Reinforcement and Development, Research, and Technology Ministry of Higher Education of Republic of Indonesia, No. 36/a/E/KPT/2016 (valid until 2021). 